journal homepage:http://chimie-biologie.ubm.ro/carpathian_journal/index.html

\title{
EFFECTS OF PUMPKIN (CUCURBITA MOSCHAT) / SOYBEAN (GL YCINE MAX)FLOUR BLENDS ON FUNCTIONAL, PHYSIC-CHEMICAL PROPERTIES AND SENSORY ATTRIBUTES OF BREADS PRODUCED FROM WHOLE WHEAT (TRITICUM AESTIVUM L)
}

\begin{tabular}{|c|c|}
\hline \multicolumn{2}{|c|}{ Demelash Hailu Mitiku $^{1 凶}$ and Tizazu Yirga Bereka ${ }^{1}$} \\
\hline${ }^{1}$ Department of Postharve & $\begin{array}{l}\text { ent, College of Agriculture and Veterinary Medicine, Jimma Universit } \\
\text { P.O.Box 307,Ethiopia } \\
\text { 'hailudeme@gmail.com }\end{array}$ \\
\hline ttps://doi.org/10.34302/ & 1.13 .1 .11 \\
\hline Article history: & ABSTRACT \\
\hline $\begin{array}{l}\text { Received: } \\
\text { 3 September } 2020 \\
\text { Accepted: } \\
\quad 5 \text { February } 2021 \\
\end{array}$ & $\begin{array}{l}\text { Bread is an important staple food in many countries. Bread making is } \\
\text { currently limited to wheat and a few other commonly used cereal seeds in } \\
\text { many countries. This study was initiated with the objective of determining } \\
\text { the effect of pumpkin/soybean flour blends on functional, physicochemical }\end{array}$ \\
\hline $\begin{array}{l}\text { Keywords: } \\
\text { composite bread; } \\
\text { pumpkin; } \\
\text { soybean; } \\
\text { proximate composition and } \\
\text { sensory evaluation. }\end{array}$ & $\begin{array}{l}\text { properties and sensory attributes of composite wheat, pumpkin and soy } \\
\text { bread. The result indicated that the proximate compositions of breads } \\
\text { produced with the different mix ratios of wheat, pumpkin and soybean flours } \\
\text { were ranged from } 11.07 \text { to } 13.19 \% \text { for moisture, } 1.15 \text { to } 2.15 \% \text { for ash, } 1.18 \\
\text { to } 1.54 \% \text { for fiber, } 16.31 \text { to } 18.74 \% \text { for fat, } 14.22 \text { to } 17.33 \% \text { for protein, } \\
60.24 \text { to } 66.78 \% \text { for carbohydrates and } 470.79 \text { to } 478.95 \mathrm{kcal} / 100 \mathrm{~g} \text { for } \\
\text { energy. The result showed that as the supplementation level of pumpkin and } \\
\text { soybean flour increases, the ash, fiber, fat and protein of the composite bread } \\
\text { produced were increased. However, the carbohydrate contents of the } \\
\text { produced bread were decreased. The sensory evaluation of bread produced } \\
\text { were in acceptable range even though, there were decreasing as the } \\
\text { supplementation level of the pumpkin and soybean increased. These finding } \\
\text { produced bread of acceptable nutritional, functional and sensory qualities } \\
\text { from } 3.5 \text { to } 10.5 \% \text { of pumpkin and } 1.5 \text { to } 4.5 \% \text { of soybean flour with wheat, } \\
\text { therefore, these research findings have shown new windows for further } \\
\text { utilization of pumpkin and represents one way of cutting down on the large } \\
\text { amounts of wheat importation for bread making and other wheat flour based } \\
\text { products. }\end{array}$ \\
\hline
\end{tabular}

\section{Introduction}

Bread is among the most common foods prepared through fermentation and is a major food for mankind; thus bread making is one of the oldest processes known (Plessas et al., 2005). The word bread is used to describe the whole range of different bread varieties which may vary in weight, shape, crust hardness, crumb cell structure, softness, colour and eating quality (Collins, 1995).

In Ethiopia, bread is an important staple food. However, bread making is currently limited to wheat and a few other commonly cereal seeds in any countries. Anjum et al (2005) reported that wheat is the main ingredients in bread preparation being used as a dietary staple, averaging that two-third of total consumption in the world.

Although, no other crop can achieve the absolute baking properties of wheat, composite flours have become the subject of numerous studies, for the developing countries. The use of composite flours have several advantages: saving of hard currency, promotion of highyielding native plant species, a better supply of protein for human nutrition and a simple 
production technology (Bugusu et al., 2001). Also, the formulation of composite flour with local staple crop results in value-added product. Thus, there is a need for studies on proper utilization of composite flours, including pumpkins and soybeans. This became a necessity of over reliance on imported wheat (Akpapunam and Darbe, 1999). Ethiopia, moreover, grows staple crops other than wheat such as cassava, sweet potato, potato, pumpkins and cereals that can be used for bakery foods. It would therefore be economically advantageous if imported wheat could be reduced and the demand for baked foods such as bread could be met by the use of domestically grown products other than wheat.

Pumpkin is from genus Cucurbita of the family Cucurbitaceae. It includessquash and cucumbers which are grown throughout the tropical and sub tropicalcountries. There are three common types of pumpkin world-wide, namely Curcurbitapepo, Curcurbita maxima and C. moschata (Lee et al., 2003). The yelloworange characteristic colour of pumpkin is due to the presence ofcarotenoid. Carotenoids are natural pigments responsible for the yellow, orange andred colour of many foods.

According to Lee et al. (2002) stated that by adding certain amount of pumpkin powder the Beta-carotene content in noodles was clearly enhanced. Pumpkin flour is a good source of food containing high and healthy amount of dietary fiber (Kulaitiene et al, 2014). Moreover, pumpkin contains high content of Beta-carotene, pectin, some vitamin, material salts. Pumpkin also included the various source of carotenoids and ascorbic acids (Caili, 2006) which have important roles in nutrition as provitamin A (antioxidant).

According to research, they claim that foods include high level of Beta-carotene that may reduce the risk of cancer, protect heart, delay aging and body generation (Krinsky and Johnson, 2005). Beta-carotene may help lower the risk of metabolic syndrome (Sugiura et al. (2015), may protect the skin from the sun's damaging UV rays (Stahl and Sies, 2012). Vitamin A is known as a strong natural antioxidant and it is necessary for preserve the integrity of skin and mucosa and also an essential vitamin for good eyesight. Besides pumpkins also provide lots of riboflavin, potassium, copper, manganese and smaller significant amount of niacin, folate, phosphorus and iron.

Although there is surplus production of pumpkins in Ethiopia, consumption of pumpkin based fermented foods like bread is not widely practiced like that of wheat in rural and urban areas. Thus, implementation of composite flour technology is thought to be an appropriate intervention to improve the physicochemical composition of bread, there by showing an alternative way of utilizing pumpkins by humans which is limited only for stew preparation. The aim of the research is, therefore, to study the effects of progressive supplementation of pumpkin/soybean flour blends on physicochemical properties and sensory attributes of breads produced from wheat composite flours. The outcomes of the study is used to generate baseline information for subsequent studies that focus on pumpkinbased value added products improvement and related programmes in the country.

\section{Materials and methods}

\subsection{Experimental materials}

The experiment was conducted at Wollega University Shambu Campus in Food science and Nutrition laboratory and Jimma University College of Agriculture and Veterinary Medicine Department of Food Science and Postharvest Technology laboratory. The raw materials used for bread production pumpkin (Cucurbita moschat) was obtained at Bako market and soybean (Glycine max) (Didessa) variety was obtained from Bako agricultural research center. Whole wheat flour, salt, sugar and oil were purchased from Jimma city.

\subsection{Production of pumpkin flour}

Fresh pumpkin were washed, trimmed and peeled to make them free from soil, rotting or insect damage. The pumpkin pieces were then cut into slices. The slices of pumpkins were washed, spread evenly on different trays and then dried in an oven at $55^{\circ} \mathrm{C}$ for 24 hours. The 
dry pumpkins were milled into flour using laboratory grinder and passed through $250 \mu \mathrm{m}$ sieve and obtain uniform sized flours. The flour was then packed in sealed plastic bag and stored at ambient temperature till further used.

\subsection{Production of soybean flour}

The soybean were thoroughly sorted and cleaned to remove foreign materials from the lot. Then ,the soybeans were cleaned by clean water and soaked in boiled water at $100^{\circ} \mathrm{C}$ for 30 minutes to facilitate the removing of coat and separated the beans from the hull in cold water. Then, the soybeans were dried in an oven at $100^{\circ} \mathrm{C}$ for 6 hours. The dried soybeans were grinded by laboratory grinder into flours. Then, the flours were sieved through $250 \mu \mathrm{m}$ and obtained uniform sized flours. Finally, the flours were packed in plastic large and stored at ambient temperature till further used (Edema et al., 2005).

\subsection{Experimental design}

The experiment were carried out by completely randomized design with a single factor of four blending ratio with three replications were used. The blending ratio with one control (100\% wheat flours) and the other is pumpkin, soybean and wheat flours with different supplementation level. The proportion wheat: pumpkin: soybean flour, 100:0:0; 95: 3.5: 1.5 ; $90: 7: 3$; and 85: 10.5: 4.5, respectively.

Table 1. Experimental Formulation

\begin{tabular}{|l|l|l|l|}
\hline Blending ratio & Pumpkin flour (\%) & Soybean flour & Wheat flour (\%) \\
\hline B0 & 00 & 00 & 100 \\
\hline B1 & 3.5 & 1.5 & 95 \\
\hline B2 & 7.0 & 3.0 & 90 \\
\hline B3 & 10.5 & 4.5 & 85 \\
\hline
\end{tabular}

Where; $\mathrm{B} 0=100 \%$ wheat flour, $\mathrm{B} 1=3.5 \%$ pumpkin flour $+1.5 \%$ soybean flour $+95 \%$ wheat flours, $\mathrm{B} 2=7 \%$ pumpkin flour $+3 \%$ soybean flour $+90 \%$ wheat flours, $B 3=10.5 \%$ pumpkin flour $+4.5 \%$ soybean flour $+85 \%$ wheat flours

\subsection{Bread preparation}

Bread was prepared by straight dough methodof AACC optimized straight dough bread making method 10-10B(AACC, 10th edition, 2000).Bread production process (mixing and kneading,bulk fermentation, molding, rounding, intermediate proofing, molding, final proofing, baking,cooling and packaging). The control flour $(100 \%$ wheat flour (B0)), blended at ratios of 3.5\% Pumpkin flour: 1.5\%soy flour: $95 \%$ wheat flour; $7 \%$ pumpkin flour: 3\% soy flour: $90 \%$ wheat flour and $10.5 \%$ pumpkin flour: $4.5 \%$ soy flour: $85 \%$ wheat flour were employed for the production of bread. The baking formula were $100 \mathrm{~g}$ of flour, wheat flour or the blend, $2 \mathrm{~g}$ yeast, $1 \mathrm{~g}$ bread improver, $2 \mathrm{~g}$ salt and $180 \mathrm{ml}$ water. All ingredients were mixed in a bowl manually for 15 minutes. All ingredients were placed in plastic bowls and mixed for exactly 10 to 15 minutes until non- stickyhomogeneous dough were formed. The dough was fermented in a bowl covered with polyethylene plastic in fermentation cabinet which was maintained at $27^{\circ} \mathrm{C}$ and $75 \%$ relative humidity for 60minutes. After 1 hour of fermentation the dough were taken out of the fermentation cabinet and remixed until its size was reduced almost to its original size. The dough was then kept back in the fermentation cabinet for second fermentation for 20minutes. After 20minutes the dough was taken out of the fermentation cabinet, sheeted and molded. After sheeting and molding process were completed, the dough was placed on pan which was already greased by oil and baked in oven maintained at $200^{\circ} \mathrm{C}$ for 15 minutes. Finally the bread were removed and cooled for 1 hour and packed in polyethylene bag and stored in a cool and dry area. 


\subsection{Chemical composition}

The chemical composition of the compositebread produced and the flour of wheat, pumpkin and soybean, including moisture, crude fat, crude protein, crude fiber and total ash were determined using AOAC official methods of $925.09,4.5 .01,979.09$ and 923.03, respectively (AOAC, 2000). Total carbohydrate was determined by difference. Results were expressed as g/100 g of dry matter. Energy value was calculated using Atwater's conversion factors, where carbohydrates and proteins give $4 \mathrm{kcal} / \mathrm{g}$ while lipids give $9 \mathrm{kcal} / \mathrm{g}$ (Osborne and Voogt, 1978).

\subsection{Total carotenoid contents}

Total carotenoids content of pumpkins flour and bread samples were determined according Bandyopadhyay et al. (2008). Pumpkin flour and composite bread sample $(5 \mathrm{~g})$ were mixed with $37.5 \mathrm{ml}$ methanol and $12.5 \mathrm{ml}$ of $50 \%$ Potassium hydroxide solution in a flask for saponification. Then unsaponifiable materials were extracted twice with Diethyl ether $(20 \mathrm{ml}$ each time) and the ether extract was washed twice with distilled water $(40 \mathrm{ml}$ each time).Next, the extract was dried over anhydrous sodium sulfate. The diethyl ether was evaporated on steam bath and the dried residue was then re-dissolved in petroleum ether (20 $\mathrm{ml})$. The yellow to orange color of the petroleum ether was measured at wavelength of $450 \mathrm{~nm}$ with a Spectrophotometer. The Total Carotenoids content of samples was computed using the formula shown below and the result was reported in mg equivalent of $\beta$ - carotene per $\mathrm{kg}$ of sample.

\subsection{Functional properties of flours \\ 2.8.1.Bulk density}

Bulk density was determined following the method described by Eleazu and Ironua (2013) and Onabanjo and Dickson (2014). A 10ml graduated cylinder, previously tarred, was gently filled with $5 \mathrm{~g}$ of sample. The bottom of the cylinder was gently tapped on a laboratory bench several times until there was to a constant.
The bulk density of the sample $(\mathrm{g} / \mathrm{ml})$ was calculated as weight of the sample per unit volume of sample.

\subsubsection{Water absorption capacity}

Water absorption capacity was determined according to the method used byAbdlwahab et al. (2009).10\% suspension of the sample was mixed with glass rod in centrifuge tube for $2 \mathrm{~min}$ at room temperature. After $20 \mathrm{~min}$ of shaking the suspension was centrifuged for $30 \mathrm{~min}$ at 4000 $\mathrm{rpm}$ at room temperature. The free water was decanted into a $10 \mathrm{ml}$ graduated cylinder and the volume was recorded. Water absorption capacity (WAC) was estimated as the amount of water retained by 100 grams materials.

\subsubsection{Oil absorption capacity}

The oil absorption capacity was estimated by the method used by Abdlwahab et al. (2009) and wasexpressed as the amount of oil bound by 100 grams dry matter. $10 \%$ suspensions of the sample were mixed with glass rod in centrifuge tube for $2 \mathrm{~min}$ at room temperature. After $20 \mathrm{~min}$ of shaking the suspension was centrifuged for 30 min at $4000 \mathrm{rpm}$ at room temperature. The freed water was decanted into a $10 \mathrm{ml}$ graduated cylinder and the volume was recorded.

\subsection{Sensory evaluation of bread}

Sensory evaluation of bread samples were carried out according to the method described by Barnes et al. (1991) by 45 untrained panelists at Jimma University College of Agriculture and Veterinary Medicine in the department of Food Science and Postharvest Technology laboratory. The samples were served in random order, identified by three digits codes.Panelists were advised to avoid strong odorous materials, such as soaps, lotions and perfumes prior to participating on panels and to avoid eating, drinking or smoking at least 30 minutes prior to a sensory test. Consumers were asked to fill questionnaire prepared for the evaluated sensory attributes of the bread samples, i.e.,color, appearance, body and texture, flavor and overall acceptability using a 9- point hedonic scale (1 dislike extremely, $5=$ neither like nor dislike, 9 $=$ like extremely). Packaged drinking water was provided for rinsing their mouth between samples. 


\subsection{Statistical analysis}

All the data obtained were subjected to analysis of variance (ANOVA). The mean \pm standard error of mean were determined for all the data and were separated by least significance difference (LSD) at $\mathrm{P} \leq 0.05$, using SAS computer software.

\section{Results and discussions}

The results of functional properties of wheat, pumpkin and soybean flour are presented in the (Table 2). The functional properties determine the application and use of food material for various products. For instance properties are very important for the appropriateness of the diet, particularly for growing children (Omueti et al., 2009). The respective results showed significant $(P<0.05)$ differences between wheat, pumpkin and soybean flour.

The bulk density value of wheat flour was $0.61 \mathrm{~g} / \mathrm{ml}$ whereas those of pumpkin and soybean flours amounted to 0.51 and $0.55 \mathrm{~g} / \mathrm{ml}$ respectively. There were significant $(P<0.05)$ difference among all the flours. This finding was in agreement with work of Van Toan and Thuy (2018) on their work of production of high quality flour and made biscuits from pumpkin. Bulk density is affected by the particle size and density of the flour and it is very important in determining the packaging requirement, material handling and application in wet processing food industry (Karuna et al., 1996).
The lower the bulk desnity, the higher the amount of flour particles that can bind together leading to higher energy values (Onimawo and Egbekum, 1998).

The water absorption capacity and oil absorption capacity of the wheat flour were 2.01 and $1.39 \mathrm{~g} / \mathrm{ml}$ respectively. Oil absorption capacity (OAC) of flour is important as it improves the mouth feel and retains the flavor. Flours of pumpkin and soybean had 0.51 and $0.55 \mathrm{~g} / \mathrm{ml}$ water absorption capacity and 0.81 and $2.62 \mathrm{ml} / \mathrm{g}$ of oil absorption capacity. There were also significant differences $(P<0.05)$ between the flours in their water absorption and oil absorption capacity. The highest and lowest swelling index were recorded in wheat flour and soybean flour with values of (3.70 and 2.79) respectively. There were significant $(P<0.05)$ different among all the flours.

The highestvalue oftotal carrotenoid content was recorded in pumpkins flour with value of $5.66 \mathrm{mg} / \mathrm{kg}$ and the lowest has recorded in wheat flour with value of $0.07 \mathrm{mg} / \mathrm{kg}$. The wheat, pumpkin and soybean flour showed significance $(P<0.05)$ difference. This an indication that pumpkin flour contains higher total carrotenoids as compared to wheat and soybean flours used for this study. According to many scholars, they claim that foods that have high level of betacarotene reduce the risk of cancer, protect heart and delay aging and body generation (Krinsky and Johnson, 2005).

Table 2.Functional properties and Total carotenoids of wheat, pumpkin and soybean flours

\begin{tabular}{|c|c|c|c|c|c|}
\hline Sample & $\begin{array}{c}\text { Bulk } \\
\text { Density } \\
(\mathrm{g} / \mathrm{ml})\end{array}$ & $\begin{array}{c}\text { Water } \\
\text { Absorption } \\
\text { Capacity }(\mathrm{ml} / \mathrm{g})\end{array}$ & $\begin{array}{c}\text { Oil Absorption } \\
\text { Capacity }(\mathrm{ml} / \mathrm{g})\end{array}$ & $\begin{array}{c}\text { Swelling } \\
\text { Index } \\
(\%)\end{array}$ & $\begin{array}{c}\text { Total } \\
\text { Carotenoids } \\
(\mathrm{mg} / \mathrm{kg})\end{array}$ \\
\hline wheat flour & $0.61 \pm 0.01^{\mathrm{a}}$ & $2.01 \pm 0.02^{\mathrm{b}}$ & $1.39 \pm 0.02^{\mathrm{c}}$ & $3.70 \pm 0.01^{\mathrm{a}}$ & $0.07 \pm 0.01^{\mathrm{b}}$ \\
\hline pumpkin flour & $0.51 \pm 0.01^{\mathrm{c}}$ & $0.81 \pm 0.01^{\mathrm{c}}$ & $1.63 \pm 0.01^{\mathrm{a}}$ & $3.61 \pm 0.01^{\mathrm{b}}$ & $5.66 \pm 0.02^{\mathrm{a}}$ \\
\hline soybean flour & $0.55 \pm 0.01^{\mathrm{b}}$ & $2.62 \pm 0.02^{\mathrm{a}}$ & $1.51 \pm 0.02^{\mathrm{b}}$ & $2.79 \pm 0.01^{\mathrm{c}}$ & $0.11 \pm 0.01^{\mathrm{c}}$ \\
\hline LSD & 0.03 & 0.06 & 0.05 & 0.04 & 0.04 \\
\hline CV & 2.47 & 1.62 & 1.71 & 0.65 & 1.06 \\
\hline
\end{tabular}

Where, LSD = least significance differences, $C V=$ Coefficient of variation. Values are means \pm standard error of three replicates and means with the same letter in the column are not significantly different at 5\% level of significance. 
Table 3. Proximate composition of wheat, pumpkin and soybean flour

\begin{tabular}{|l|c|c|c|c|c|c|c|}
\hline Sample & $\begin{array}{c}\text { Moisture } \\
(\%)\end{array}$ & $\begin{array}{c}\text { Ash } \\
(\%)\end{array}$ & $\begin{array}{c}\text { Fiber } \\
(\%)\end{array}$ & $\begin{array}{c}\text { Fat } \\
(\%)\end{array}$ & $\begin{array}{c}\text { Protein } \\
(\%)\end{array}$ & $\begin{array}{c}\text { Carbohydrate } \\
(\%)\end{array}$ & $\begin{array}{c}\text { Energy } \\
(\mathrm{kcal} / 100 \mathrm{~g})\end{array}$ \\
\hline wheat flour & $10.37 \pm$ & $1.92 \pm$ & $0.60 \pm$ & $2.46 \pm$ & $10.46 \pm$ \\
$0.02^{\mathrm{b}} \pm$ & $84.56 \pm 0.02^{\mathrm{b}}$ & $402.25 \pm 0.12^{\mathrm{b}}$ \\
& $0.19^{\mathrm{b}}$ & $0.02^{\mathrm{c}}$ & $0.01^{\mathrm{c}}$ & $0.01^{\mathrm{b}}$ & $0.04^{\mathrm{b}}$ & & \\
\hline pumpkin & $11.52 \pm$ & $2.39 \pm$ & $1.77 \pm$ & $0.56 \pm$ & $2.31 \pm$ & $92.96 \pm 0.03^{\mathrm{a}}$ & $386.13 \pm 0.05^{\mathrm{c}}$ \\
flour & $0.04^{\mathrm{a}}$ & $0.01^{\mathrm{b}}$ & $0.02^{\mathrm{b}}$ & $0.01^{\mathrm{c}}$ & $0.02^{\mathrm{c}}$ & & \\
\hline soybean & $9.61 \pm$ & $4.08 \pm$ & $5.35 \pm$ & $16.47 \pm$ & $34.98 \pm$ & $39.12 \pm 0.07^{\mathrm{c}}$ & $444.65 \pm 0.56^{\mathrm{a}}$ \\
flour & $0.02^{\mathrm{c}}$ & $0.05^{\mathrm{a}}$ & $0.02^{\mathrm{a}}$ & $0.06^{\mathrm{a}}$ & $0.05^{\mathrm{a}}$ & & \\
\hline LSD & 0.40 & 0.11 & 0.05 & 0.13 & 0.14 & 0.16 & 1.15 \\
\hline CV & 1.92 & 1.93 & 1.03 & 1.02 & 0.44 & 0.11 & 0.14 \\
\hline
\end{tabular}

Where, $\mathrm{LSD}=$ Least significance difference, $\mathrm{CV}=$ Coefficient of variation. Values are means \pm standard error of three replicates and means with the same letter in the column are not significantly different at $5 \%$ level of significance.

\subsection{Proximate composition of wheat, pumpkin and soybean flour}

The proximate composition of the wheat, pumpkin and soybean flour were analyzed for moisture content, ash, protein, fat, fiber, carbohydrates and energy (Table 3). The moisture contents of wheat, pumpkin and soybean flour showed significance $(P<0.05)$ differences and the highest value was recorded in pumpkin with value of $11.52 \%$ and the lowest was recorded in soybean flour with value of $9.61 \%$. The variation of moisture contents may be attributed to the genetic composition and also agro cultural practices (Ingabire and Hild, 2011).

The ash contents of wheat, pumpkin and soybean flour were showed significance $(P<0.05)$ differences from each other having the highest value in soybean flour $4.08 \%$ and the lowest value in wheat flour with the value of $1.92 \%$. Similar works have been reported by Gerhard and Saeleaw (2010) who worked on composition, physicochemical and morphological characterization of pumpkin flour.

The fiber contents of wheat, pumpkin and soybean flour were found significantly $(P<0.05)$ different from each other. Soybean had greater crude fiber contents $(5.35 \%)$ than wheat $(0.60 \%)$ and pumpkin $(1.77 \%)$ flour. People who consume generous amounts of dietary fiber have health protective effect in comparison with those who have minimal fiber intake. Dietary fiber has recently gained much importance as it is said to reduce colon cancer, diabetes, heart diseases and the level of low density lipoprotein cholesterol in blood (Kulaitiene, 2014).

The crude fat contents were showed significance $(P<0.05)$ differences among each other and the highest value were found in soybean flour with value of $16.47 \%$ and the lowest was found in pumpkin flour with the value of $0.56 \%$. Similar findings was reported by Mesfin and Shimelis (2013) on their work of bread produced for soybean and quality maize flour.

The protein contents of wheat, pumpkin and soybean flour showed significant $(P<0.05)$ different among each other. The highest protein content was found in soybean flour (34.98\%) and the lowest were recorded in pumpkin with value of $2.31 \%$. Pumpkin contains the lowest protein content as compared to wheat and soybean flours. Thus, pumpkin flours are recommended for those people of gluten intolerance.

The carbohydrate content of wheat flour, pumpkin and soybean flours were 84.56, 92.96 and $39.12 \%$ respectively. The result of wheat, pumpkin and soybean flour exhibited significant $(P<0.05)$ differences between them. Pumpkin flour contains higher carbohydrate contents than wheat and soybean flour.On the other hand, the energy contents of wheat, pumpkin and soybean flours were 402.25, 386.13 and 444.65 $\mathrm{kcal} / 100 \mathrm{~g}$, respectively and exhibited significant $(P<0.05)$ differences among each other. The energy content differences could be due to 
variation in their protein, fat and carbohydrate contents (Giami et al., 2000).

\subsection{Proximate composition of breads from blends of wheat, pumpkin and soybean flour.}

The proximate compositions of breads produced with the different mix ratios of wheat, pumpkin and soybean flours are presented in (Table 4). The highest (13.19\%) and lowest $(11.07 \%)$ moisture contents of composite bread produced from wheat, pumpkin and soybean flour were observed from samples with $(10.5 \%$ pumpkin, $4.5 \%$ soybean and $85 \%$ wheat) and $100 \%$ wheat breads. There was significance $(P<0.05)$ difference in moisture content of whole wheat bread as compared to the all treatments. However, there was no significance $(P<0.05)$ differences between $3.5 \%$ and $7 \%$ pumpkin flour supplementations. Similar works were reported by Adriana and Simona 2014 on their works of physicochemical and sensory evaluations of wheat bread with pumpkin.

The highest ash contents were recorded in $10.5 \%$ pumpkin and $4.5 \%$ soybean flour supplementation and the lowest were recorded in $100 \%$ wheat flour breads with value of $2.15 \%$ and $1.51 \%$ respectively. The results of ash contents showed significance $(P<0.05)$ differences among the treatments and the ash contents of whole wheat bread were significantly $(P<0.05)$ different from those of pumpkin and soybean treatments. As the supplementation of pumpkin and soybean flour increases the ash contents were increased which is an indication of increment in mineral contents. This finding was in agreement with the work of Aniedu and Agugo, (2010) who reported that the ash content increased with progressive increase in supplementation of fruit flour in wheat for bread production.

The crude fiber result obtained in $10.5 \%$ pumpkin and $4.5 \%$ soybean flour were higher than those of pure wheat bread samples, implying that addition of pumpkin and soybean flour increases crude fiber. The highest values were recorded in $10.5 \%$ pumpkin and $4.5 \%$ soybean flour supplementation with value of $1.54 \%$. The crude fiber contents of the composite breads made by adding flours of both pumpkin and soybean exhibited significant $(P<0.05)$ differences from that of whole wheat breads. The crude fiber contents increased progressively with increased proportion of pumpkin and soybean flour. This increase in crude fiber content of the breads of the composite flours is the effect of the relatively higher percentage (1.77 and 5.35\%) of crude fiber present in pumpkin and soybean flours (Table 3).

The highest and lowest fat contents were recorded in $10.5 \%$ pumpkin flour, $4.5 \%$ soybean flour and $100 \%$ whole wheat flours with value of $18.74 \%$ and $16.31 \%$ respectively. The result showed significance $(P<0.05)$ differences between the whole wheat bread and among all the treatments. The results revealed that fat content of the breads of composite flours increased as the proportion of pumpkin and soybean flour addition increased. This due to high level of fat in soybean flour (Table 3).

The lowest protein content was found in whole wheat bread with value of $14.22 \%$ and highest were recorded in composite breads having $10.5 \%$ pumpkin and $4.5 \%$ soybean flour with value of $17.33 \%$. There were significant $(P<0.05)$ different among the composite breads produced and with whole wheat breads. The protein content increased as percentage of pumpkin and soybean flours increased. This may have been due to the high protein content of soybean flours. This is similar to the works of Olaoye et al., 2006 on their work of quality characteristics of bread produced from composite flours of wheat, plantain and soybeans.

Regarding carbohydrate contents of the breads made from the composite flours of wheat, pumpkin and soybean flours, significantly higher values were recorded in whole wheat breads as compared to the other treatments. As the supplementation level of pumpkin and soybean flour increases, the carbohydrate contents was decreased. Similar findings were reported by Olaoye et al., 2006.

The energy contents of breads made from composite flours of wheat, pumpkin and soybean ranged from 470.79 to 478.95 $\mathrm{kcal} / 100 \mathrm{~g}$, with significant $(P<0.05)$ differences 
among them. The energy content increased with increase in proportion of pumpkin and soybean flour. The lowest energy content was recorded for whole wheat breads and the highest was recorded in $10.5 \%$ pumpkin and $4.5 \%$ soybean supplementation respectively.

Table 4.Proximate composition of breads produced from blends of wheat, pumpkin and soybean flour

\begin{tabular}{|c|c|c|c|c|c|c|c|}
\hline Sample & $\begin{array}{c}\text { Moisture } \\
(\%)\end{array}$ & $\begin{array}{c}\text { Ash } \\
(\%)\end{array}$ & $\begin{array}{c}\text { Fiber } \\
(\%)\end{array}$ & $\begin{array}{c}\text { Fat } \\
(\%)\end{array}$ & $\begin{array}{c}\text { Protein } \\
(\%)\end{array}$ & $\begin{array}{c}\text { Carbohydrate } \\
(\%)\end{array}$ & $\begin{array}{c}\text { Energy } \\
(\mathrm{kcal} / 100 \mathrm{~g})\end{array}$ \\
\hline B0 & $11.07 \pm$ & $1.51 \pm$ & $1.18 \pm$ & $16.31 \pm$ & $14.22 \pm$ & $66.78 \pm 0.06^{\mathrm{a}}$ & $470.79 \pm$ \\
& $0.11^{\mathrm{c}}$ & $0.02^{\mathrm{d}}$ & $0.01^{\mathrm{c}}$ & $0.01^{\mathrm{d}}$ & $0.02^{\mathrm{d}}$ & & $0.10^{\mathrm{d}}$ \\
\hline B1 & $12.54 \pm$ & $1.71 \pm$ & $1.22 \pm$ & $17.11 \pm$ & $15.14 \pm$ & $64.81 \pm 0.06^{\mathrm{b}}$ & $473.83 \pm$ \\
& $0.08^{\mathrm{b}}$ & $0.02^{\mathrm{c}}$ & $0.02^{\mathrm{c}}$ & $0.01^{\mathrm{c}}$ & $0.03^{\mathrm{c}}$ & & $0.12^{\mathrm{c}}$ \\
\hline B2 & $12.76 \pm$ & $1.80 \pm$ & $1.35 \pm$ & $17.65 \pm$ & $16.22 \pm$ & $62.98 \pm 0.04^{\mathrm{c}}$ & $475.65 \pm$ \\
& $0.05^{\mathrm{b}}$ & $0.01^{\mathrm{b}}$ & $0.01^{\mathrm{b}}$ & $0.02^{\mathrm{b}}$ & $0.02^{\mathrm{b}}$ & & $0.07^{\mathrm{b}}$ \\
\hline B3 & $13.19 \pm$ & $2.15 \pm$ & $1.54 \pm$ & $18.74 \pm$ & $17.33 \pm$ & $60.24 \pm 0.08^{\mathrm{d}}$ & $478.95 \pm$ \\
& $0.08^{\mathrm{a}}$ & $0.03^{\mathrm{a}}$ & $0.01^{\mathrm{a}}$ & $0.04^{\mathrm{a}}$ & $0.03^{\mathrm{a}}$ & & $0.20^{\mathrm{a}}$ \\
\hline LSD & 0.28 & 0.07 & 0.04 & 0.08 & 0.08 & 0.20 & 0.42 \\
\hline CV & 1.20 & 1.99 & 1.88 & 0.24 & 0.28 & 0.17 & 0.05 \\
\hline
\end{tabular}

Where, LSD; Least significance difference, $\mathrm{CV}=$ Coefficient of variation. Values are means \pm standard error of three replicates and means with the same letter in the column are not significantly different at $5 \%$ level of significance. $\mathrm{B} 0=100 \%$ wheat Flour; $\mathrm{B} 1=3.5 \%$ pumpkin flour $+1.5 \%$ soybean flour $+95 \%$ wheat flour; $\mathrm{B} 2=$ $7 \%$ pumpkin flour $+3 \%$ soybean flour $+90 \%$ wheat flour; B3 $=10.5 \%$ pumpkin flour $+4.5 \%$ soybean flour + $85 \%$ wheat flour.

Table 5. Sensory evaluation of breads made of wheat, pumpkin and soybean flour

\begin{tabular}{|c|c|c|c|c|c|c|}
\hline Sample & Taste & Aroma & Texture & $\begin{array}{c}\text { Crust } \\
\text { color }\end{array}$ & Crump color & $\begin{array}{c}\text { Overall } \\
\text { Acceptability }\end{array}$ \\
\hline B0 & $7.09 \pm$ & $6.78 \pm$ & $6.42 \pm$ & $6.58 \pm$ & $6.80 \pm 0.01^{\mathrm{a}}$ & $7.09 \pm 0.03^{\mathrm{a}}$ \\
& $0.02^{\mathrm{a}}$ & $0.02^{\mathrm{a}}$ & $0.02^{\mathrm{a}}$ & $0.02^{\mathrm{a}}$ & & \\
\hline B1 & $6.48 \pm$ & $6.38 \pm$ & $6.19 \pm$ & $6.36 \pm$ & $6.18 \pm 0.01^{\mathrm{b}}$ & $6.61 \pm 0.01^{\mathrm{b}}$ \\
& $0.01^{\mathrm{b}}$ & $0.01 \mathrm{~b}^{\mathrm{a}}$ & $0.02^{\mathrm{b}}$ & $0.03^{\mathrm{b}}$ & & \\
\hline B2 & $5.77 \pm$ & $5.97 \pm$ & $5.70 \pm$ & $6.48 \pm$ & $6.41 \pm 0.01^{\mathrm{c}}$ & $6.42 \pm 0.01^{\mathrm{c}}$ \\
& $0.02^{\mathrm{c}}$ & $0.33^{\mathrm{b}}$ & $0.01^{\mathrm{c}}$ & $0.01^{\mathrm{c}}$ & & \\
\hline B3 & $5.36 \pm$ & $5.18 \pm$ & $5.40 \pm$ & $5.58 \pm$ & $5.76 \pm 0.01^{\mathrm{d}}$ & $5.49 \pm 0.02^{\mathrm{d}}$ \\
& $0.03^{\mathrm{d}}$ & $0.03^{\mathrm{c}}$ & $0.01^{\mathrm{d}}$ & $0.01^{\mathrm{d}}$ & & \\
\hline LSD & 0.08 & 0.55 & 0.05 & 0.06 & 0.04 & 0.06 \\
\hline CV & 0.68 & 4.78 & 0.46 & 0.54 & 0.34 & 0.51 \\
\hline
\end{tabular}

Where, LSD; Least Significance Difference, $C V=$ Coefficient of Variation, B0 $=100 \%$ wheat Flour; B1 $=3.5 \%$ pumpkin flour $+1.5 \%$ soybean flour $+95 \%$ wheat flour; B2 $=7 \%$ pumpkin flour $+3 \%$ soybean flour $+90 \%$ wheat flour; B3 $=10.5 \%$ pumpkin flour $+4.5 \%$ soybean flour $+85 \%$ wheat flour. Values are means \pm standard error of three replicates and means with the same letter in the column are not significantly different at $5 \%$ level of significance.

\subsection{Sensory evaluation of breads made of wheat, pumpkin and soybean flour}

Sensory acceptability data of breads produced by blending wheat, pumpkin and soybean flours are presented in (Table 5). The taste acceptability score ranges from 5.36 to 7.09. There were significant $(P<0.05)$ differences among the treatments and also with whole wheat breads. The aroma acceptability score ranges from 5.18 to 6.78 in $10.5 \%$ pumpkin and $4.5 \%$ soybean supplementation and $100 \%$ wheat breads produced. Statistically aroma didn't showed significance differences between the whole wheat breads and 3.5\% 
pumpkin and $1.5 \%$ soybean composite breads. However, there was significance $(P<0.05)$ differences between the whole wheat breads and composite breads supplements with $7 \%, 10.5 \%$ pumpkin and $3 \%$ and $4.5 \%$ soybean flour breads.

The texture acceptability scores ranged from 5.40 to 6.42 and exhibited significance $(P<0.05)$ differences between the whole wheat breads and among all the treatments in the composite breads produced. The highest texture score was recorded in 100\% wheat bread and the lowest was recorded in 10.5\% pumpkin and 4.5\% supplementation of soybean flour. The crust and crumb color of composite bread produced by supplementing pumpkin and soybean decreased when the addition of pumpkin and soybean flour increased. As the supplementation level of pumpkin and soybean flour increased, the brightness of the crust and crumb color of composite were recorded in the whole wheat breads and the lowest was recorded in $10.5 \%$ pumpkin and $4.5 \%$ soybean flour.

The overall acceptability evaluation of the breads which are presented in the same table showed significant $(P<0.05)$ difference between breads whole wheat breads and composite breads produced from addition of pumpkin and soybean at different level. The highest overall acceptability of breads was recorded in whole wheat breads and the lowest were recorded in $10.5 \%$ pumpkin and $4.5 \%$ soybean supplemented. In general, the overall acceptability of breads decreased, as the supplementation level of pumpkin and soybean flour increased.

\section{Conclusions}

The use of pumpkin and soybean in supplementing wheat flour in bread production has significant benefits in countries like Ethiopia where inadequate wheat is grown. Therefore, incorporation of pumpkin and soybean flour in bread production will reduce the quantity of wheat that will be imported, thereby reducing the cost of production of breads. These finding produced bread of acceptable nutritional, functional and sensory qualities from 3.5 to $10.5 \%$ of pumpkin and 1.5 to $4.5 \%$ of soybean flour with wheat, therefore, these research findings have shown new windows for further utilization of pumpkin and represents one way of cutting down on the large amounts of wheat importation for bread making and other wheat flour based products.It is recommended that up to $10.5 \%$ pumpkin flour and $4.5 \%$ soybean flour substitution could be adopted in bread making processes, without affecting the quality adversely.

\section{References}

Adriana and Simona, (2014). Phsico-chemical and sensory evaluations of wheat bread withpumpkin (Cucurbita maxima) pulp incorporated. Journal of Agro alimentary Processes and Technologies, 20(1), 26-32.

Akpapunam,M.A., Darbe, J.W., (1999). Chemical composition and functional properties of blend of maize Barbara Groundnuts Flours for cookies production. Plants Food for Human Nutrition, 46, 147155.

Aniedu, C. and Agugo, U.A. (2010). Acceptability of bread produced from Hausa-potato and sweet potato composite flours. Journal of Agriculture and Social Research 10(2), 162-166.

Anjum, T., R. Bajwa and A. Javaid. (2005). Biological Control of Parthenium I: Effect of Imperatacylindrica on distribution, germination and seedling growth of Parthenium hysterophorus L. International Journal of Agriculture and Biology, 7(3), 448-450.

AOAC. (2000). Association of official andanalytical chemists, 15th Ed (Helrich, K.). Arlington, Virgina, USA.

AOAC.(1990).Official Methods of Analysis, Assiciatin of Analytical Chemists, Washington,D.C

Barnes, D.L., Harper, S.J. and Bodyfelt, F.W. (1991a). Prediction of Consumer Acceptability of Yoghurt by Sensory and Analytical Measures of Sweetness and Sourness. Journal of Dairy Science, 74, 3746-3754

Bugusu, B. A., Campanella, O., \& Hamaker, B. R. (2001). Improvement of sorghum-wheat 
composite dough rheological properties and breadmaking quality through zein addition. Cereal chemistry, 78(1), 31-35.

Caili, F., Huan, S., Quanhong, L. (2006). A review on pharmacological activities and utilization technologies of pumpkin. Plant foods for human nutrition. 61(2), 70-77.

Collins, B.(1995), Bread making processes: In: National Association of Master Bakers (Ed). The master baker's book of bread making, Hertfordshire: Swallowfield Associates Limited , 1-46.

Edema, MO, Sanni LO and AI Sanni (2005). Evaluation of maize-soybean flour blends for sour maize bread production in Nigeria. African Journal of Biotechnology. 4: 911918.

Eleazu, C., Ironua , C.( 2013). Physicochemical composition and antioxidant properties of a sweetpotatovariety (Ipomoea batatas L) commercially sold in South Eastern Nigeria. African Journal of Biotechnology.; 12(7).

FAO, (2011).Statistical database. http://faostat.fao.org

Giami, S.Y., Adindu, M.N., Akusu, M.O. and Emelike, J.N.T. (2000). Compositional, functional and storage properties of flour from raw and heat processed African bread fruit (Trecuia Africana decne). Plant Foods for Human Nutrition; 55, 357 -368.

Ingabire, M.R. and Hilda, V. (2011). Comparison of the Nutrient composition of flour sweet potato varities cultivated in Rwanda. American Journal of Food and Nutrition, 1(1), 34-38.

Karuna D, Noel D, Dilip K. (1996). Food and nutrition bulletin. United Nation. 17(2).

Krinsky N.I.\& Johnson E.J. (2005). Carotenoid actions and their relation to health and diseas. Molecularaspects of medicine.; 26(6),459-516.

Kulaitiene, Danilcenko H, Jariene E, Jukneviciene E, Jukneviciene E. (2014). Pumpkin fruit flour as a source for food enrichment in dietary fiber. Notulae Botanicae Horti Agrobotanici Cluj-Napoca. 42(1), 19.

Lee, C.H., Cho, J.K., Lee, S.J, Koh, W., Park W., Kim, CH.(2002). Enhancing $\beta$ -
Carotene Content in Asian Noodles by Adding Pumpkin Powder. Cereal Chemistry. 79(4),593-595.

Lee, F.A. (1983). Basic Food Chemistry. AVI Publisher, Westport. Pongjanta, J., Jomduang, S. and Panomwan $\mathrm{Na}$ Ayuttaya, R. 2003. Effect of processing and dying treatment on quality of pumpkin powder. Food J. 33, 68-76.

Mesfin W and Shimelis A(2013). Effect of soybean/cassava flour blend on the proximatecomposition of ethiopian traditional bread prepared from quality protein maize. African Journal of Food, Agriculture, Nutrition and Development. 13(4), 1684-5374

Onimawo, A.I., Egbekun, K.M.(1998). Comprehensive Food Science and Nutrition. Macmillan Publishers, Ibadan, 228

Omueti, O., - Otegbayo, B., - Jaiyeola, O., Afolabi, O. (2009). Functional properties of complementary diets developed from soybean (Glycine max), groundnut (Arachis hypogea) and crayfish (Macrobrachium SPP). In EJEAFChe, vol. 8(8), 563-573.

Olaoye, O.A., Onilude, A.A., and Idowu O.A. (2006). Quality characteristics of bread produced from composite flours of wheat, plantain ad soybeans. African Journal of Biotechnology,vol. 5(11), 1102-1106.

Onabanjo, O., Dickson, A. (2014). Nutritional, functional and sensory properties of biscuit produced from wheat-sweet potato composite. Journal of Food Technology Research, 1:111-121.

Plessas, S., Pherson, L., Bekatorou, A., Nigam, P., and Koutinas, A.A. (2005). Bread making using kefir grainsas baker's yeast. Food Chemistry. 93, 585-589.

Stahl W, Sies H. $\beta$ - Carotene and other carotenoids in protection from sunlight. The American journal of clinical nutrition. 2012; 96(5),1179S-1184S.

Sugiura M, Nakamura M, Ogawa K, Ikoma Y, Yano M. High serum carotenoids associated with lower risk for the metabolic syndrome and its components among Japanese subjects- Mikkabi cohort study. British 
Journal of Nutrition. 2015; 114(10),16741682.

\section{Acknowledgements}

The authors would like to acknowledge the financial assistance provided by Wollega University and Jimma University College of Agriculture and Veterinary Medicine Department of Food Science and Post harvest technology. The author also thanks Ayana Fekadu, and laboratory technicians involved directly or indirectly for the accomplishment of the manuscript. 